\title{
T-Cell Receptor Profile
}

National Cancer Institute

\section{Source}

National Cancer Institute. T-Cell Receptor Profile. NCI Thesaurus. Code C129657.

A data set that both identifies and quantifies the alpha/beta or gamma/delta T-cell receptors in a biological sample or specimen. 